\title{
35. WESTERN NORTH ATLANTIC UPPER JURASSIC CALCAREOUS NANNOFOSSIL BIOSTRATIGRAPHY
}

\author{
Frank H. Wind, Antarctic Research Facility, Department of Geology, \\ Florida State University, Tallahassee, Florida ${ }^{1}$
}

\begin{abstract}
Stratigraphic ranges of key Upper Jurassic and lowermost Cretaceous nannofossil species are revised on the basis of a comprehensive review of previously published biostratigraphic studies. Both the known ranges and the highest and lowest possible occurrences of key taxa, on the basis of an assessment of the paleoecological and preservational phenomena affecting Upper Jurassic and lowermost Cretaceous nannofloral composition, were considered in preparation of the proposed biostratigraphic revision.

The identification of several Upper Jurassic evolutionary lineages and the synonymy of Upper Jurassic and Lower Cretaceous forms indicate that several previously recognized biostratigraphic datum planes are incorrect or unreliable as age indicators. Stage assignment for Upper Jurassic sediments from DSDP Leg 11, Site 105 , are revised in light of the proposed biostratigraphic revision.

During DSDP Leg 44 well-preserved Upper Jurassic sediments containing a diverse nannofossil assemblage were recovered at Hole 391C. The oldest samples recovered are lower (?) Kimmeridgian. The Jurassic/Cretaceous boundary is placed within an extensive interval of sediments containing poorly preserved nannofossils, at a point between the highest occurrence of Hexalithus noelae and the lowest occurrence of Lithraphidites carniolensis.
\end{abstract}

Microstaurus quadratus Black is transferred to Cretarhabdus.

\section{INTRODUCTION}

DSDP Hole 391C (Leg 44) in the Blake-Bahama Basin (latitude $28^{\circ} 13.7^{\prime} \mathrm{N}$; longitude $75^{\circ} 36.9^{\prime} \mathrm{W}$ ) was cored during September 1975. Drilling at the site, in 4973 meters of water, penetrated to a sub-bottom depth of 1412 meters.

Cores 34 through 44 (1219.0 to $1325.5 \mathrm{~m}$ sub-bottom depth) were dated aboard the Glomar Challenger as Upper Tithonian-lower Berriasian. Cores 45 through 54 (1323.5 to $1412.0 \mathrm{~m}$ sub-bottom depth) were dated as lower Tithonian. Higher cores in this sequence are largely limestone, clayey limestone, and limestone with clayey stringers, while the deeper half of this interval (below approximately Core 46) is largely clayey limestone, calcareous claystone, and calcareous mudstone. Calcareous nannofossils are generally poorly preserved in the limestone, with extensive dissolution and precipitation. In contrast, preservation of the calcareous nannoflora in the more clay-rich deeper units is exceptionally good and provides some of the best preserved Upper Jurassic nannofossil floras yet available.

\section{RESEARCH TECHNIQUES}

Smear slides and slides from settled suspensions were prepared from all samples provided. One cover slip from each sample was coated in a Denton vacuum-

'Present address: Texaco Inc., Los Angeles, Ca. coater with carbon and gold-palladium as if the sample were to be viewed on the scanning electron microscope. The cover slip was then joined to a microscope slide with Caedex utilizing standard slide assembly and curing procedures. Although the carbon and goldpalladium film reduces the intensity of the crossedpolarized light image, it greatly improves resolution when utilizing phase-contrast illumination. This technique is especially useful when examining Jurassic samples, whose podorhabdid nannofloral components are often difficult to resolve with either crossedpolarized light or phase-contrast illumination.

\section{PREVIOUS UPPER JURASSIC AND LOWER CRETACEOUS BIOSTRATIGRAPHIC STUDIES}

Few comprehensive studies of Upper Jurassic and lower Cretaceous nannofossils are available for reference. Brönnimann (1955) first studied Upper Jurassic and lowest Cretaceous nannoconid floras in detail; Trejo (1960) provides range charts and an identification key for speciation of these forms. Noël (1956, 1958) studied Upper Jurassic sediments in Algeria, reporting new taxa and biostratigraphy. Stradner (1963), as part of a stratigraphic study of Mesozoic coccoliths, proposed a generalized biostratigraphic division of the Jurassic. Noël (1965a, b) studied lowermost Jurassic through Valanginian nannoplankton floras using the transmission electron microscope. Because she placed emphasis upon systematic paleontology, she paid little attention to refining the 
then present biostratigraphy. Her monograph (1965a), however, is the principal foundation upon which subsequent endeavors are based. Lezaud (1967) studied Callovian through lower Kimmeridgian nannofloras in samples from northern France.

Thierstein $(1971,1973)$ proposed a Lower Cretaceous calcareous nannofossil zonation and reviewed the systematic paleontology of Cretaceous floras. Rood and Barnard (1972) studied the evolution and biostratigraphy of Stephanolithion, Diadozygus, and related genera from the Jurassic and earliest Cretaceous. Noël (1972 [1973]) describes calcareous nannofossils from several Oxfordian and Kimmeridgian localities in France and England.

A key reference for Jurassic nannofossil biostratigraphy is Barnard and Hay (1974). However, it is somewhat incomplete in that it does not include the Portlandian (upper Tithonian or upper Volgian), and their reference sections are riddled with several significant barren zones, particularly in the Kimmeridgian. Much of their zonation, especially in the Kimmeridgian, is based upon poorly preserved material.

More recently, Grün (in Allemann, Grün, and Wiedmann, 1975) described uppermost Tithonian and lower Cretaceous nannofloras from a section in southern Spain. Unfortunately, several of the taxa listed in range charts by Grün bear numbers rather than species names, and their relationships to presently recognized forms is not known. Thierstein (1975) studied Upper Jurassic-Lower Cretaceous sections from Europe, and the western North Atlantic, and the western Pacific oceans. Thierstein (1976) is a comprehensive review of Mesozoic calcareous nannofossil systematic paleontology, paleoecology, paleobiogeography, and biostratigraphy. Cooper and Shaffer (1976) discuss the nannofossil biostratigraphy of the Bossier Shale and the Jurassic/Cretaceous boundary in Louisiana.

Jurassic nannofloras recovered by Glomar Challenger as part of the Deep Sea Drilling Project have been reported in Bukry and Bramlette (1969, Leg 1); Worsley (1971, Leg 1); Wilcoxon (1972, Leg 11); Proto Decima (1974, Leg 27); and Wise and Wind (1977, Leg 36). Upper Jurassic sediments were also recovered at Site 367 (Leg 41).

\section{STRATIGRAPHIC RANGES OF KEY UPPER JURASSIC AND LOWER CRETACEOUS NANNOFOSSIL SPECIES}

It is essential in biostratigraphic investigations to consider not only the known range of an individual taxon, but also the highest and lowest possible occurrences, on the basis of the paleoecology and preservation effects on composition of nannofloras in the sections studied. The presently recognized and revised ranges of these and other species are shown in Figure 1.

\section{Stephanolithion bigoti Deflandre, 1939} (Plate 1, Figures 1-4)

Stephanolithion bigoti Deflandre, 1939, p. 1332, textfig. 1-14.

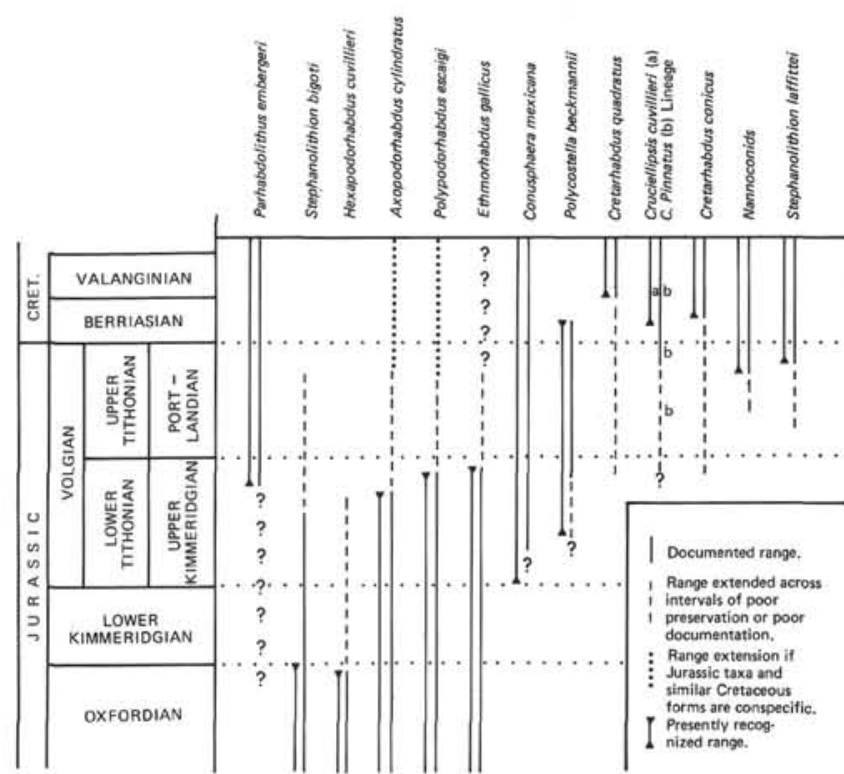

Figure 1. Suggested revision of Upper Jurassic nannoplankton biostratigraphy.

Stradner (1963), Medd (1971), Barnard and Hay (1974), and Thierstein (1976) extend the known range of this species to the end of the Oxfordian. Both Thierstein (1975) and Proto Decima (1974) interpret the presence of this species as indicating pre-Kimmeridgian sediments. Rood and Barnard (1972) state that S. bigoti is abundant in Callovian sediments and occurs in the Oxfordian sediments. The species became extinct during the Oxfordian. However, Noël (1956, 1965a, 1972) extends the ranges of this species into the upper Kimmeridgian (although possibly not as high as the Pectinatites pectinatus [Ammonite] Zone). Lezaud (1967) indicates that $S$. bigoti are abundant in Oxfordian sediments, and occur rarely in a sample from the Aulacostephanus mutabilis (Ammonite) Zone. The presence of $S$. laffittei in the upper Portlandian (Noël, 1956, 1965a) suggests that the absence of all members of this genus in the intervening section is because of poor preservation, and not because of the absence of stephanolithionid-bearing algae during the late Kimmeridgian and early Portlandian. Stradner et al. (1968, p. 42) state that the ultrastructure of S. laffittei corresponds well to that of $S$. bigoti. Rood and Barnard (1972) illustrate a similar zone of nonpreservation in the lineage of Diadozygus and related genera.

Bukry and Bramlette (1969, p. 374) report in Sample 1-5A-7, CC the presence of $S$. bigoti, S. laffittei, and a form intermediate between the two. The deepest sample at Hole $5 \mathrm{~A}$ is probably Upper Jurassic (upper Portlandian). With the exception of this one DSDP sample, the youngest documented occurrence of $S$. bigoti is upper Kimmeridgian and the latest probable time of the extinction of $S$. bigoti is therefore middle or late Portlandian (late Tithonian).

Axopodorhabdus cylindratus (Noël), Wind and Wise, 1977

Podorhabdus cylindratus Noël, 1965a, p. 103-104, textfig. 30, pl. 9, fig. 3,7 . 
Podorhabdus septendrionalis Black, 1971, p. 407-408, pl. 32, fig. 5 .

Axopodorhabdus cylindratus (Noël), Wind and Wise in Wise and Wind, 1977 , p. 297 , pl. 80 , fig. 5, 6, pl. 81 , fig. $1-4$, pl. 88 , fig. 5,6 .

Wind and Wise (in Wise and Wind, 1976) propose the genus Axopodorhabdus for podorhabdids with four perforations separated by four pillars which are aligned along the major and minor axes of the rhabdolith rim. Although this designation is equivalent to that of Podorhabdus (Noël, 1965a), the holotype of the latter genus bears only two perforations, rather than four. This condition necessitated the emendation of the genus Podorhabdus to conform to the newly recognized features of the holotype of the type species, $P$. grassei Noël. Medd (1971) and Barnard and Hay (1974) indicate that this species ranges into the Kimmeridgian. The latter reference extends the range of this species through the Pectinatites pectinatus (Ammonite) Zone. As Axopodorhabdus septendrionalis (Black), it has also been reported from Berriasian through Hauterivian sediments.

Axopodorabdus cylindratus (Noël) and Axopodorhabdus dietzmanni (Reinhardt) are probably two portions of a single long-ranging lineage. Both species are characterized by central areas which are generally not visible in crossed-polarized light; a feature used to distinguish the latter species from Axopodorhabdus orbiculofenestratus (Gartner). Black (1972, p. 33) notes that both $A$. cylindratus and $A$. dietzmanni possess a second, inner, cycle of elements on the distal surface of the rim.

The only feature distinguishing A. dietzmanni and $A$. cylindratus is the presence of a broader short axis strut in the former species. The widening of this strut accounts for the higher length-to-width ratio for $A$. dietzmanni, and a more elongate central area defined by the position of the four central area perforations. I have measured seven Callovian and Oxfordian specimens of $A$. cylindratus figured in various publications; these specimens give a range in rim eccentricity of from 1.15 to 1.40 , with a mean value of 1.28 . Ratios of central area dimensions range from 1.09 to 1.54 , with a mean value of 1.28. Specimens of $A$. septentrionalis from the Berriasian have rim dimension ratios of between 1.28 and 1.33, and inner area perforated region dimension ratios of between 1.30 and 1.41. Illustrated specimens of $A$. dietzmanni in Bukry (1969), Thierstein (1971), and Black (1972) generally generate corresponding values of 1.30 to 1.40 (rim ellipticity), and 1.45 to 1.82 (central area dimensions). An Albian specimen identified by Black as Podorhabdus sp. cf. P. septentrionalis (1972, pl. 6, fig. 2) has a rim dimension ratio 1.27 and a central area ratio of 1.37 . This form, in both dimensions and general appearance typifies what I would consider to be a from intermediate between the Jurassic and lower Cretaceous Axopodorhabdus cylindratus, and the younger Axopodorhabdus dietzmanni.

\section{Hexapodorhabdus cuvillieri Noël, 1965} (Plate 1, Figure 5)

Hexapodorhabdus cuvillieri Noël, 1965a, p. 105-106, pl. 9, fig. 4-6.
Although $H$. cuvillieri has only been reported from Bajocian through uppermost Oxfordian sediments (Noël, 1965a; Medd, 1071; Barnard and Hay, 1974), evidence exists for extending its range to as high as upper Kimmeridgian. The calcareous nannofossil component of the Kimmeridgian section studied by Barnard and Hay (1974) has suffered extensive dissolution (see Barnard and Hay [1974, p. 578, 580] for a discussion of lithologies sampled and microfossil preservation). Floral composition of the lower and middle Kimmeridgian sediments studied by Barnard and Hay (1974) indicates dissolution of the lessresistant microfloral components. Although absent from this portion of the section, many species reappear in the better-preserved upper Kimmeridgian floras. The relative abundance of a given species in the Kimmeridgian samples of Barnard and Hay is likely to directly indicate the species' ability or inability to withstand syndepositional or post-depositional dissolution. The podorhabdids, as a group, appear to be rather susceptible to dissolution, and in the Kimmeridgian, are present only in the youngest samples which have the greatest floral diversity and are probably the best preserved. A similar relationship of general floral preservation to the presence or absence of podorhabdids was noted in the Oxfordian section recovered on DSDP Leg 36 (see Wise and Wind, 1977). An additional feature of podorhabdid preservation is that as a rule, the species-diagnostic central area is invariably the first portion of the coccolith to be dissolved or disarticulated.

The absence of specimens of $H$. cuvillieri in the Kimmeridgian studied by various authors may also be caused by the generally poor representation of this species in Upper Jurassic nannofloras even within its documented stratigraphic range. This species was found in only 6 of 79 Oxfordian samples studied by Medd (1971). Most of these samples contained specimens of Axopodorhabdus, Polypodorhabdus, and Ethmorhabdus.

The presence of this species in the uppermost Oxfordian, and its absence in upper Kimmeridgian sediments studied by Noël (1965a, 1972 [1973]), suggest that the highest probable occurrence is upper Kimmeridgian (lower Tithonian). However, the small number of well-preserved upper Kimmeridgian samples researched, and the low abundance of this form even within its documented range indicate that additional samples and research are needed before the definitive last occurrence datum of this species can be determined.

\section{Polypodorhabdus escaigi Noël, 1965}

Polypodorhabdus escaigi Noël, 1965a, p. 109-110, textfig. 32, pl. 10, fig. 6-8.

Polypodorhabdus madingleyensis Black, 1971, p. 408, pl. 32, fig. 7.

Noël (1972 [1973]) indicates that the highest occurrence of this species is upper Kimmeridgian. Barnard and Hay (1974) extend the range of this species into the highest ammonite zone of the Kimmeridgian. $P$. madingleyensis Black is given a range of Oxfordian to Aptian (Black, 1971, p. 390, table 3; p. 408). Grün 
and Allemann (1975) report this species in the Berriasian of Spain.

\section{Polycostella beckmannii Thierstein, 1971}

Polycostella beckmannii Thierstein,1971, p. 483, p. 2, fig. 5-16.

Thierstein (1973) cites a known range for this species of lower Tithonian to lower Berriasian. It has been reported from the uppermost lower Tithonian sample from Broyon (Ardèche), France, and one Berriasian sample from Montsalvens, Switzerland. Other researchers may not have recognized this species in Kimmeridgian sediments largely because of the general appearance and construction of this form. Although easily identifiable in the light microscope, in electron microscopes this species appears as a nondescript sedimentary particle or as cristobalite spheres.

\section{Hexalithus noelae (Noël) Loeblich and Tappan}

Hexalithus hexalithus Noël, 1958, p. 170, fig. 24. Hexalithus noelae (Noël), Loeblich and Tappan, 1966, p. 144.

Cooper and Shaffer (1976) indicate that the extinction level of this species approximates the top of the Jurassic in Louisiana.

\section{Ethmorhabdus gallicus Noël, 1965}

Ethmorhabdus gallicus Noël, 1965a, p. 110-112, textfig. 33,34 , pl. 10, fig. 1, 2, 5 .

Cribrosphaera hauteriviana Black, 1971, p. 421, pl. 33, fig. 8 .

Barnard and Hay (1974) indicate that this species ranges through the upper Kimmeridgian $P$. rotunda (Ammonite) Zone. Black (1971) illustrates a single specimen which he called Cribrosphaera hauteriviana. These two forms appear to be identical, but I am hesitant to extend the range of Ethmorhabdus gallicus into the Cretaceous on the basis of a single Hauterivian specimen. If the Hauterivian specimen is reworked from the Jurassic, then the highest valid occurrence of E. gallicus is probably uppermost Kimmeridgian or lower Portlandian.

\section{Conusphaera mexicana Trejo, 1969}

(Plate 1, Figure 21)

Particule calcaire Noël, 1965a, pl. 28, fig. 7, 9.

Conusphaera mexicana Trejo, 1969, p. 6, pl. 1, fig. 1-9; pl. 2, fig. 1-8; pl. 3, fig. 1-7; pl. 4, fig. 1-4. Cretaturbella rothii Thierstein, 1971 , p. 483 , pl. 3, fig. 1-5.

Genus ? Species ? Wilcoxon, 1972, pl. 11, fig. 2-4.

Thierstein (1975) states that the first occurrence of this species is within or below the lower Tithonian, and that the base of the $C$. mexicana Zone, which is marked by the first occurrence of $C$. mexicana or Polycostella beckmannii, lies within or below the lower Tithonian, i.e., below the Subplanites contiguus [Ammonite] Zone). Thierstein (1976) indicates the base of the range of this species is at the base of the Tithonian.

\section{Cruciellipsis cuvillieri (Manivit) Thierstein, 1971 (Plate 1, Figures 6, 7)}

Coccolithus cuvillieri Manivit, 1966, p. 268, fig. 2, 3.
Cruciellipsis cuvillieri (Manivit), Thierstein, 1971, p. 478, pl. 5, fig. 4-8.

?Cruciplacolithus pinnatus Black, 1971, p. 397, pl. 30, fig. 5 .

Thierstein (1973) states that this species first appears in lower Berriasian sediments. In 1971, Black named Cruciplacolithus pinnatus, a Hauterivian form, which although illustrated only in proximal view, bears a striking resemblance to C. cuvillieri. Grün, in Allemann et al. (1975), indicates Cruciellipsis pinnatus as first appearing in the upper Tithonian and persisting into the Valanginian. The overlap in the ranges of these two species, as well as their similar appearance, help explain the discrepancies noted when comparing the range of C. cuvillieri at DSDP Site 105 as plotted by Wilcoxon (1972) and Thierstein (1975). Pinpointing the first occurrence of $C$. cuvillieri becomes largely dependent upon one's own concept of the morphological variation allowable for this species. Wilcoxon (1972) apparently permitted greater variability within this species than did Thierstein (1975), and subsequently, may have included earlier forms in what appears to be a $C$. pinnatus- $C$. cuvillieri evolutionary lineage. Grün and Allemann (1975) place the first occurrence of this form in the uppermost Tithonian.

\section{Cretarhabdus quadratus (Black) Wind, n. comb.} (Plate 1, Figures 8, 9)

Microstaurus quadratus Black, 1971, p. 404, pl. 32, fig. 2 .

Description: Elliptical form with distal shield of approximately 26 to 32 elements and a central area bearing a wide multi-elemental cross whose arms expand laterally as they approach the rim elements. The arms are often slightly offset from the elliptical axes of the rim. A short blocky spine may be present.

Remarks: Black (1971, p. 404) notes that this form possesses a podorhabdid rim. However, on the light microscope, the image generated in both crossedpolarized and phase contrast illumination is clearly cretarhabdid. The presence of more than 16 distal shield elements prevents the placement of this species in Prediscosphaera, and the central area diameter is often larger than the diameter of the shield which precludes a transfer to Cruciellipsis. This form is similar to Retecapsa Black, which, although described by Black (1971) as having a podorhabdid rim, may also possess a cretarhabdid rim. Thierstein $(1976$, p. 350$)$ places species of Retecapsa in synonymy with Cretarhabdus angustiforatus.

Range: Tithonian (this report), Berriasian and Hauterivian (Black, 1971).

\section{Parhabdolithus embergeri (Noël) Stradner}

Discolithus embergeri Noël, 1958, p. 164, pl. 1, fig. 1, $7,8$.

Parhabdolithus embergeri (Noël), Stradner, 1963, p. 174 , pl. 4, fig. 1, 1a, 1 b.

Barnard and Hay (1974, p. 597, fig. 3) indicate that this species first occurs in upper Kimmeridgian sediments of southern England in the Subplanites wheatleyensis (Ammonite) Zone. They did not find this species in any samples from northern France. Even 
though Barnard and Hay state that Parhabdolithus embergeri is restricted in the Jurassic to the Kimmeridgian (and by inference, also the Portlandian), they identify as $P$. embergeri (Noël) a specimen from the Oakley Beds at Millbrook (Bedfordshire) (pl. 3, fig. 13). This portion of the section is dated in Rood et al. (1971) as upper Oxfordian. This specimen is not a true $P$. embergeri, but more likely, a representative of the transitional forms between Zeug. rhabdotus salillum to $P$. embergeri.

Unfortunately, because Noël (1958) did not specify whether the sketches were from the Portlandian, Berriasian, or Valanginian samples studied, the age of the material containing the type specimens is not known. Noël (1958) states that this species ranges in size from $12 \mu \mathrm{m}$ to $24 \mu \mathrm{m}$; Lauer (in Grun et al., 1972) indicates it ranges from $8 \mu \mathrm{m}$ to $15 \mu \mathrm{m}$ and Grün and Allemann (1975) cite a size range of from 9 to $16 \mu \mathrm{m}$. Measurements of specimens of Parhabdolithus embergeri illustrated in recent publications indicate a size range of from $7.5 \mu \mathrm{m}$ to $14.0 \mu \mathrm{m}$.

Differing from the more massive representatives of this species most noticeable in the Cretaceous, the form observed in the Leg 44 material appears to largely represent the Zeugrhabdotus salillum-Parhabdolithus embergeri transition. Specimens are between $8 \mu \mathrm{m}$ and $9 \mu \mathrm{m}$ in greatest dimension. Specimens are recorded as $P$. embergeri in the range chart (Figure 3 ) only when intensification of a concentric band on the rim, highlighting differentiation of inner and outer zones, is clearly visible. In addition, at this point, the central crossbar is generally viewed in crossed-polarized light as a solid bright rhombohedron.

\section{Zeugrhabdotus salillum Noël, 1965}

Zygolithus erectus Deflandre in Deflandre and Fert, 1954 , p. 150 , pl. 15 , fig. 14,15 (non 16,17 ); textfig. 62 (non 60,61 ).

Discolithus salillum Noël, 1965a, p. 72-74, text-fig. 5, 6; pl. 1, fig. 8-12.

Discolithus salillum Noël, 1965b, p. 4, fig. 5, 6 .

Zygolithus erectus Deflandre [partim] Stradner et al., 1968 , p. $34-35$, pl. 25 , pl. 26, fig. $1,2$.

Zygolithus erectus Deflandre-Lezaud, 1967, pl. 1, fig. 16, 18.

Zeugrhabdotus noeli Rood et al., 1971, p. 252-253, pl. 1, fig. 4.

non Zeugrhabdotus salillum (Noël), Rood et al., 1971, p. 253 , pl. 1 , fig. 5 .

Zeugrhabdotus noeli Rood, Hay, and Barnard, Barnard and Hay, 1974, pl. 3, fig. 8; ?pl. 6, fig. 7.

Parhabdolithus embergeri (Noël), Barnard and Hay, 1974, pl. 3, fig. 13; pl. 6, fig. 12.

Parhabdolithus embergeri (Noël), Proto Decima, 1974, pl. 7, fig. 14; non pl. 5, fig. 19, 20, 24.

? Zygodiscus salillum (Noël), Proto Decima, 1974, pl. 4, fig. 35.

Zeugrhabdotus noeli Rood, Hay, and Barnard, Noël, 1972 (1973), p. 99-100, pl. 1, fig. 1-4.

This form is characterized by a rim constructed of large, imbricate elements and a broad crossbar with a central pore surrounded by an elevated rim of angular or lobate crystals. Specimens are generally between 3.0 and $5.0 \mu \mathrm{m}$ in greatest dimension, although larger specimens, in excess of $9.0 \mu \mathrm{m}$ in length, are illustrated from the Oxfordian and Albian.

The holotype of Zeugrhabdotus salillum Noël is 2.9 $\mu \mathrm{m}$ in greatest dimension; the paratype, $3.0 \mu \mathrm{m}$. $Z$. salillum is best illustrated in Noël (1965a, 1965b), and Stradner et al. (1968). Noël (1965a) indicates the presence of this form in the Charmouthian (=Pliesbachian) and the Oxfordian. As $Z$. noeli, it has been reported from the upper Callovian and lower Oxfordian.

Zeugrhabdotus salillum is distinguished from $Z$. erectus on the light microscope primarily by differences in the width of the rim, and dimensions and optical properties of the crossbar. The rim of $Z$. salillum is broader than that of $Z$. erectus, and may, in crossedpolarized light, be divided into inner and outer zones by a faint concentric suture. The crossbar of $Z$. salillum generally occupies between $1 / 4$ and $1 / 5$ of the length of the coccolith, and is constructed of two nearly symmetrical sets of crystal aggregates which appear to broaden inwardly. A small perforation may be visible at the center, situated along a dark suture which parallels the long axis of the coccolith. In many specimens, the two halves of the crossbar are slightly offset. The crossbar in $Z$. erectus maintains uniform width and bears a larger central pore. Dimensions of the rim and crossbar result in much larger perforations in $Z$. erectus.

The Albian specimen figured as a scanning electron micrograph and identified as Parhabdolithus embergeri in Proto Decima (1974, pl. 7, fig. 14) appears to be identical to the upper Oxfordian specimen similarly named in Barnard and Hay (1974, pl. 3, fig. 13). The former specimen has a maximum diameter of $9.5 \mu \mathrm{m}$, the latter, $9.2 \mu \mathrm{m}$. These two specimens differ from the holotype and subsequently illustrated specimens of Zeugrhabdotus salillum only in size. Thierstein (1976) states that during the Tithonian, Zygodiscus erectus increased in size continuously and evolved into Parhabdolithus embergeri. It appears more likely, however, that the true forerunner of $P$. embergeri was Zeugrhabdotus salillum. Following an increase in maximum diameter to approximately $9.0 \mu \mathrm{m}$, elements of the distal rim surface of $Z$. salillum became more numerous and more narrower. Modification of the rim was accompanied by the development of a broad proximal shield surrounding the two perforations, and elongation of the central spine.

\section{Nannoconids}

A number of nannoconid-like objects were found in the Hole 391C samples. Very few, however, were identifiable as recognized species of Nannoconus. Several distinct types of primitive nannoconids appear in the studied section. Large (generally between 6.0 and $6.5 \mu \mathrm{m}$ in any dimension) fragmented cylindrical stacks of large imbricate crystals (Plate 1, Figures 14, 20) were found in many samples. Their precise relationship to the nannoconids is not known, although the elongate forms are, in general appearance, somewhat 
reminiscent of $N$. bermudezi. Additional forms which resemble a number of established species of Nannoconus are also occasionally seen, although the only form present in large numbers in an extremely small variety which eventually generally resembles Nannoconus dolomiticus, but usually is under $5.5 \mu \mathrm{m}$ in greatest dimension. This taxon, which appears low in the section as a small, equidimensional form approximately $3.5 \mu \mathrm{m}$ in any dimension, is recorded in the range chart (Figure 2) as Nannoconus sp. In Core 49 , it is more similar to $N$. dolomiticus and is recorded in Figure 2 as Nannoconus sp. aff. $N$. dolomiticus.

In the material studied, it is difficult to pinpoint the $N$. colomi datum. One is also faced with disagreement as to whether the base of the $N$. colomi Zone, which is defined by the common to abundant occurrence of $N$. colomi, and presence of "rare to few" Lithraphidites carniolensis, and N. bronnimanni (Thierstein, 1975), is a Jurassic or Upper Cretaceous event. Thierstein (1971, p. 468 , fig. 4) indicates that $N$. colomi is present in large numbers in the upper Tithonian. Noël (1956, 1965a), reports the occurrence of nannoconids, including $N$. colomi, from mid- and upper Portlandian sediments. Trejo (1960) indicates that a number of species of Nannoconus first occur in the upper Tithonian. Trejo (1975, fig. 2) shows Nannoconus as first occurring at approximately the same level as Calpionella alpina, and having persisted throughout most of the Portlandian. Thierstein (1973) states that the Nannoconus datum (first occurrence) is a late Tithonian event and that the range of $N$. colomi is upper Tithonian to upper Barremian. Despite all this evidence, Thierstein $(1975,1976)$ sets the base of the $N$. colomi Zone as lowest Berriasian.

The base of the Nannoconus colomi Zone is probably a mid-Portlandian or upper-Portlandian (late Tithonian) event. It is definitely an Upper Jurassic datum, although possibly not as old as the Kimmeridgian/Portlandian boundary as is illustrated in van Hinte (1976, fig. 3).

\section{UPPER JURASSIC/LOWER CRETACEOUS DSDP SITES IN THE WESTERN NORTH ATLANTIC AND GULF OF MEXICO}

An understanding of nannofossil biostratigraphy at DSDP sites in the Gulf of Mexico and western North Atlantic is necessary for an accurate evaluation of the nannofossils and geologic history at Site 391.

DSDP Leg 1 scientists obtained one probable Upper Jurassic sample (1-5A-7, CC) from the Gulf of Mexico. A major difficulty in determining nannofossil floral composition in the older samples from Holes 4 and $5 \mathrm{~A}$ is that significant differences in species lists and age assignments exist between the studies undertaken by Bukry and Bramlette (1969), Worsley (1971), and Thierstein (1973). Worsley (1971, table 2) indicates that both Stephanolithion laffittei and S. bigoti are present in the four samples which he considered to be the oldest. In contrast, Thierstein (1973, fig. 17) lists $S$. laffittei in nearly all the samples studied, but indicates an absence of $S$. bigoti. Thierstein, however, did not include in his study Sample 1-5A-7, CC, which, according to his interpretation of the correct sample sequence from the

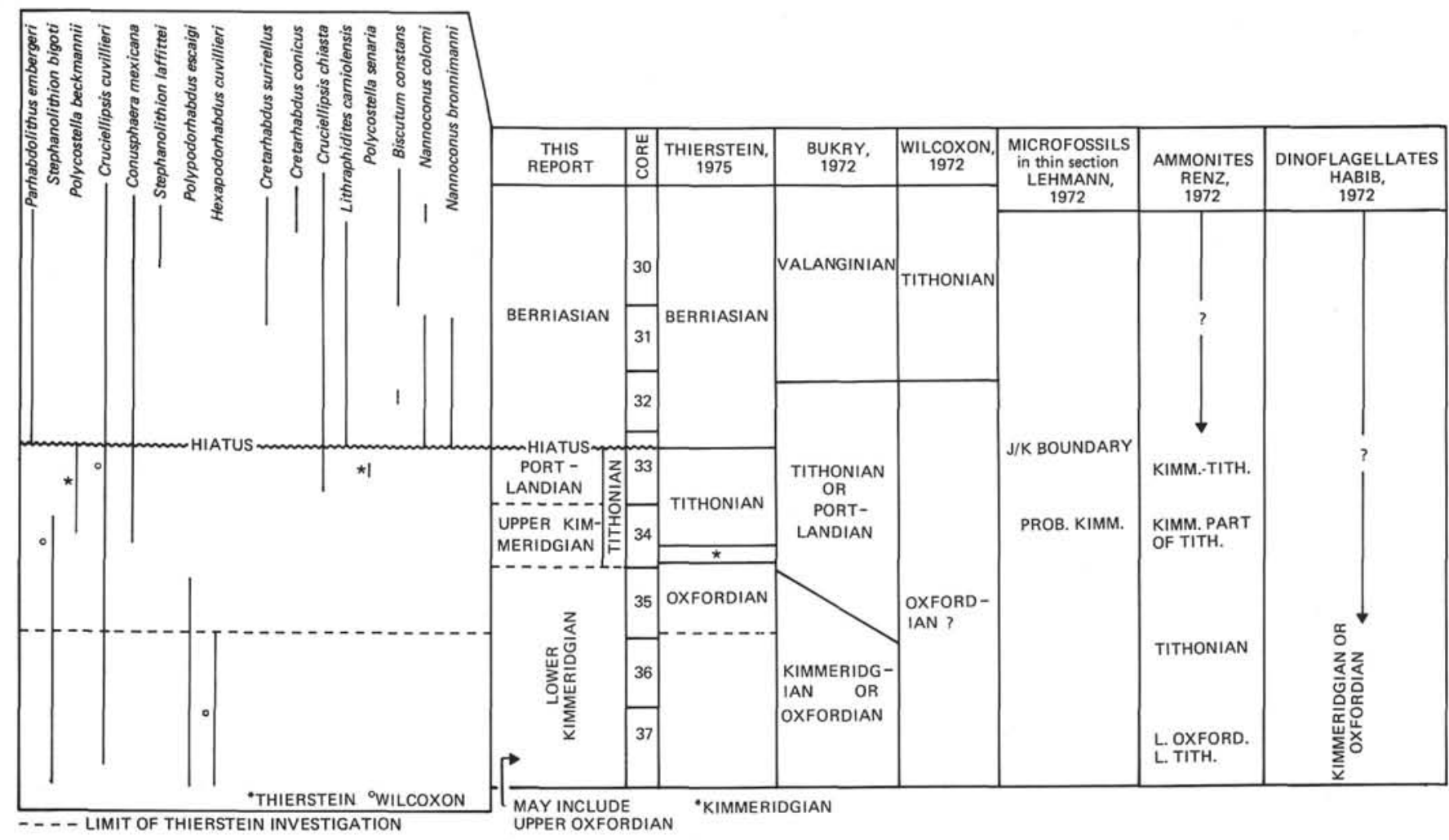

Figure 2. DSDP Hole 105 calcareous nannoplankton biostratigraphy. 
two sites, would be the oldest material recovered. Bukry and Bramlette (1969, p. 374) report the presence of $S$. bigoti, $S$. laffittei, and an intermediate form in Sample 1-5A-7, CC.

A study of Sample 1-5a-7, CC (Worsley's Sample C) suggests proximity of this sample to the Jurassic/Cretaceous boundary. A partial species list includes Diadorhombus rectus, Parhabdolithus embergeri, Tubodiscus verenae, Biscutum constans, Bidiscus spp., Rucinolithus wisei, Diazomatolithus lehmani, Lithraphidites carniolensis, Cruciellipsis cuvillieri, Tranolithus orionatus, Cretarhabdus crenulatus, Calcicalathina oblongata, Zeugrhabdotus erectus, Watznaueria spp., Cyclagelosphaera margareli, Markalius circumradiatus, rims of Sollasites, rims of podorhabdids, Stephanolithion laffittei, and etched rims of $S$. bigoti and/or the $S$. laffittei-S. bigoti transitional form.

The precise affinity of specimens of Stephanolithion from this sample is difficult to determine. Dissolution has both shortened exterior processes and removed all of the inner framework components. Specimens of $S$. laffittei are readily discernible, but specimens of different geometry are also present and consist of slightly elliptical forms usually with six short processes projecting from the polar portions of the rim.

Precise age determination of this sample is not possible. No closely overlying and underlying nannofloras are present for comparison, and whether or not any of the taxa listed above are present as a result of reworking or downhole contamination cannot be determined. The podorhabdid rims and etched stephanolithionids suggest a similar preservational history. Most of the species in this sample have only been found in the Cretaceous. The lack of detailed knowledge of the biostratigraphy of the lowermost Cretaceous and uppermost Jurassic precludes precise dating of this sampling: we do not presently know whether the major nannofloral succession from one of a typically Jurassic to a typically Cretaceous aspect is a Portlandian phenomenon or a Jurassic/Cretaceous boundary event.

Scientists aboard DSDP Leg 11 recovered Upper Jurassic sediments at three sites in the western North Atlantic off the east coasts of the United States and Cuba. Wilcoxon $(1972 a, 1972$ b) reports that all three sites contain Tithonian and Oxfordian-Kimmeridgian material. The section at Hole $105\left(34^{\circ} 54^{\prime} \mathrm{N} ; 69^{\circ} 10^{\prime} \mathrm{W}\right)$, although the most continuous, does not contain the oldest material as the lower samples from Site 100 predate the oldest material at Site 105 (Wilcoxon, 1972a).

Because of the near-completeness of the Hole 105 section, favorable preservation of its flora and its proximity to Hole $391 \mathrm{C}$ is critical for analysis of the samples from Hole 391C. In addition to nannofossils, both ammonites (primarily aptychi) (Renz, 1972) and dinoflagellates were studied from the lower portion of the section at Site 105. Neither the dinoflagellate study (Habib, 1972), nor the "microfossils observed in thin sections" report (Lehmann, 1972) was particularly useful for precise age determinations, although the latter reference cites evidence for placing the
Jurassic/Cretaceous boundary in the general region of Core 33, Section 1 .

The data from .Wilcoxon (1972b), Habib (1972), Renz (1972), and Lehmann (1972) are shown in Figure 2. Also included are nannofossil age determinations by Bukry (1972) and Thierstein (1975). The ranges of selected nannofossil species are from Thierstein (1975).

The elimination of the last occurrence of Stephanolithion bigoti as an indicator of the Oxfordian/Kimmeridgian boundary, and the extension of the possible range of Hexapodorhabdus cuvillieri permit a younger than Oxfordian age assignment for possibly all of the Site 105 section. Unfortunately, no biostratigraphic datum has been identified which approximates the Oxfordian/Kimmeridgian boundary, and as a result, the deeper portion of interval from Cores 35 through 37 may include Oxfordian sediments. The lower Kimmeridgian/upper Kimmeridgian boundary (=base of Tithonian) is placed at the first occurrence of Conusphaera mexicana.

The Kimmeridgian rather than Oxfordian date for Core 35 and the acknowledged synchroniety of the upper Kimmeridgian and Tithonian stages resolves the anomously thin Kimmeridgian section at Site 105 indicated by Thierstein (1975, p. 91, fig. 5).

Cores 33 and 34 include an unconformity and sediments dominated by Conusphaera mexicana and Polycostella beckmannii. The proliferation of these two species so dominates the nannoflora that long-ranging species, such as Zeugrhabdotus salillum, are not found in this interval. Other forms occur at what could be interpreted as anomalously high points. The first occurrences of several species lie just above the lithologic change between Sections 1 and 2 of Core 33. As result, the true first occurrence datums of Lithraphidites carniolensis, Nannoconus bronnimanni, and $N$. colomi is not preserved at Site 105. Because of poor representation of auxiliary taxa during the Conusphaera mexicana peak abundance zone, the evolutionary progression from $Z$. salillum to Parhabdolithus embergeri, the true last occurrence of Stephanolithion bigoti, and of the possible slow evolutionary change from Cretarhabdus quadratus to Cruciellipsis cuvillieri was not detected.

The review of nannofossil studies and analysis of samples from DSDP Hole 391C have prompted the following evaluation of previously proposed Upper Jurassic and lowest Cretaceous nannofossil zones.

\section{UPPER JURASSIC NANNOFOSSIL ZONATION}

\section{Watznaueria communis Zone \\ Barnard and Hay, 1974, p. 577}

Definition: Interval from the highest occurrence of Stephanolithion bigoti to the lowest occurrence of Parhabdolithus embergeri.

Remarks: The evolution of $P$. embergeri from Zeugrhabdotus salillum during the Kimmeridgian and the highest occurrence of Stephanolithion bigoti in the upper Kimmeridgian or Portlandian suggest that the datum planes defining this zone may be reversed. Unfortunately, the highest occurrence of $S$. bigoti is 
often governed by dissolution effects, while the Parhabdolithus embergeri datum is probably regulated in part, by overgrowth phenomena, as extensive reprecipitation will lower the level at which Zeugrhabdotus salillum looks like Parhabdolithus embergeri.

\section{Parhabdolithus embergeri Zone \\ Worsley, 1971, p. 1304}

Definition: Interval from the lowest occurrence of Parhabdolithus embergeri to the lowest occurrence of Nannoconus steinmanni $(=N$. colomi $)$.

Remarks: As noted above, it is often difficult to pinpoint the first appearance of Parhabdolithus embergeri. In addition, because of its restricted distribution as the result of ecological pressures and provincialism, the genus Nannoconus is not a particularly reliable marker species. Berger and Roth (1975) note that Nannoconus seems to be almost completely restricted to the Tethys Province and is much more common in nearshore deposits and small basins. Wise and Wind (1977) report that nannoconids are common in Albian and Aptian sediments from the Falkland Plateau. Possibly the geographic distribution of this genus was only greatly restricted during the latest Jurassic and earliest Cretaceous. Quite often this genus is too poorly represented in nannofossil samples to be a reliable marker, or is so abundant that it, by sheer volume and numbers, excludes many other diagnostic taxa. In addition, a nannoconid bloom generates a high-carbonate sediment which appears to be highly susceptible to diagenetic alteration.

\section{Conusphaera mexicana Zone Thierstein, 1975, p. 86}

Definition: Interval from the first occurrence of Conusphaera mexicana Trejo and/or Polycostella beckmannii Thierstein to the first occurrences of Nannoconus colomi (de Lapparant) and Lithraphidites carniolensis Deflandre.

\section{Conusphaera mexicana Zone Wind, this report}

Definition: Interval from the first occurrence of Conusphaera mexicana Trejo and/or Polycostella beckmannii Thierstein to the first occurrence of Lithraphidites carniolensis Deflandre.

Remarks: Precise paleoecological restrictions governing the distribution of Polycostella beckmannii and Conusphaera mexicana are not known. If $C$. mexicana is phylogenetically related to Nannoconus, then the two genera may have similarly to ecological and geographic conditions.

Nannoconus colomi first occurs in the upper Kimmeridgian or Portlandian and Lithraphidites carniolensis occurs first in the lowermost Berriasian.

\section{Nannoconus colomi Zone \\ Worsley, 1971, p. 1304}

Definition: Interval from the lowest occurrence of Nannoconus steinmanni Kamptner to the lowest occurrence of Diadorhombus rectus Worsley.

\section{Nannoconus colomi Zone \\ Thierstein, 1971, p. 464}

Definition: The base of this zone is marked by the first appearance of Nannoconus colomi (deLapparant) which is very abundant immediately above. The top of this zone is below the first occurrence of Cretarhabdus crenulatus Bramlette and Martini emend. Thierstein.

Remarks: Thierstein, 1973, notes that the base of this zone seems to coincide with the first occurrence of all nannoconids and approximates the base of the Calpionella Zone. Geographic and environmental restrictions governing the presence and relative abundance of Nannoconus during the latest Jurassic or earliest Cretaceous, as discussed in Berger and Roth (1975), make the first occurrence or first common occurrence of any members of this genus an unreliable datum in many areas. However, the presence of primitive nannoconids may indicate Portlandian age.

Rapidly changing Late Jurassic environments and varying degrees of preservation of key zonal taxa diminish the accuracy of specific zones as worldwide time indicators. They may have local or regional applications. The overlap of a number of zones at Site 391 suggests that major revision of the biostratigraphic zones for correlation within this period is necessary. Inasmuch as most zones are defined by the first or last occurrence of individual taxa, I discuss below individual biostratigraphic datum planes.

Potentially useful biostratigraphic datum planes for the Upper Jurassic and Jurassic/Cretaceous boundary are listed below in approximate stratigraphic order. Possible reduced utility of each datum because of dissolution and reprecipitation (*), ecological restriction $(+)$, and problems encountered in pinpointing a datum within a gradual evolutionary progression (o) are indicated where applicable.

first Parhabdolithus embergeri (*,o)

first Cretarhabdus (*)

first Cretarhabdus conicus $\left({ }^{*}\right)$

first Cruciellipsis cuvillieri $\left({ }^{*}, \mathrm{o}\right)$

first Conusphaera mexicana $(?+)$

first Nannoconus $(*)$

first Polycostella beckmanni (?+)

last Hexapodorhabdus cuvillieri $\left({ }^{*}\right)$

first Polycostella senaria

last Hexalithus noelae

first Stephanolithion laffittei (*, ?o)

last Stephanolithion bigoti $\left({ }^{*}\right.$, ?o)

first Lithraphidites carniolensis $\left({ }^{*}\right)$

Resolution of Upper Jurassic and Jurassic/Cretaceous nannofossil biostratigraphy awaits the discovery and study of a continuous sequence of marine sediments containing well-preserved nannofossils and calpionellid and ammonite faunas. At present, the Kef Talrempt Series near Ampere, Algeria, initially studied by Noël $(1956,1958,1972)$, appears to offer the best section available for study.

\section{CALCAREOUS NANNOFOSSIL BIOSTRATIGRAPHY AT SITE 391}

The distribution of Upper Jurassic nannofossil species at Site 391 is shown in Figure 3. The first 


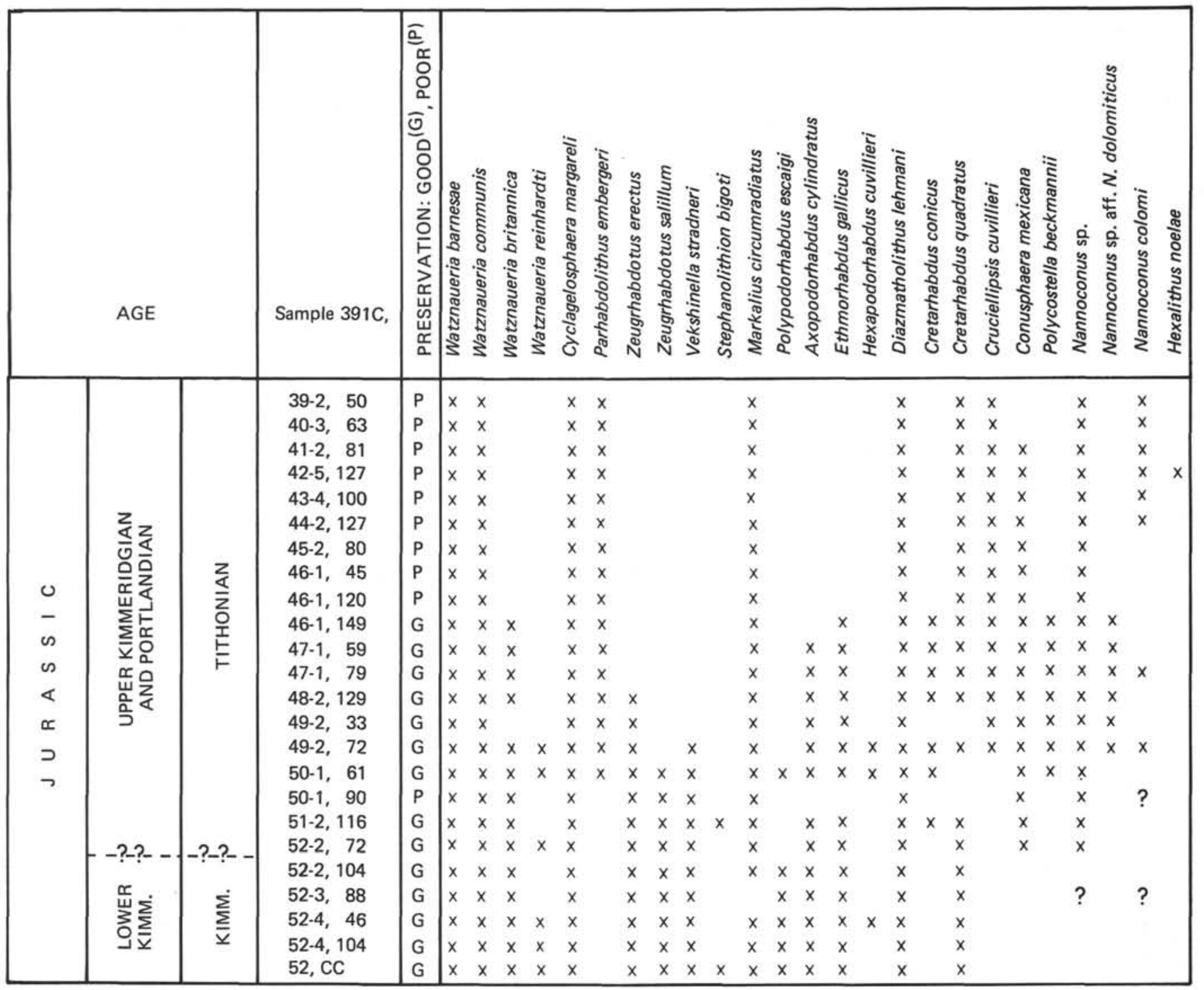

Figure 3. Distribution of Jurassic calcareous nannoplankton species at Hole 391C.

occurrence of Conusphaera mexicana in Sample 391C$52-2,72 \mathrm{~cm}$ places the base of the Tithonian (lower Kimmeridgian/upper Kimmeridgian boundary) between that sample and $391 \mathrm{C}-52-2,104 \mathrm{~cm}$. Additional study is necessary to determine the worldwide stratigraphic occurrence of C. mexicana and the degree of precision and reliability with which its first occurrence datum approximates the base of the Tithonian. Subsequent research may indicate that drilling at Site 391 failed to reach lower Kimmeridgian sediments. Unfortunately, the revised biostratigraphic zonation does not define a datum plane for recognition of the Kimmeridgian/Portlandian boundary.

The presence of Hexalithus noelae in Sample 391C$42-5,127 \mathrm{~cm}$ indicates a Portlandian age. Preservation throughout the higher portion of the section considered is too poor to record which species of Stephanolithion existed, or when Lithraphidites carniolensis first appeaaarrdd. Poorly preserved specimens of $L$. carniolensis are present in Sample 391C-36-2, $25 \mathrm{~cm}$, and the Jurassic/Cretaceous boundary is therefore placed somewhere between Cores 42 and 36 .

\section{ACKNOWLEDGMENTS}

I wish to thank the personnel of the Deep Sea Drilling Project for the opportunity to participate in the initial research on material from this cruise, and Dr. Fred M. Weaver (Exxon Production Research Company, Houston) for conveying my request for samples to the Leg 44 Chief Scientists. I thank also Dr. Hans R. Thierstein (Scripps Institution of Oceanography, La Jolla) for valuable discussions concerning Upper Jurassic nannofossil biostratigraphy. Dr. Sherwood W. Wise, Jr. (Florida State University) offered important suggestions and guidance during the final stages of research, and reviewed the manuscript.

\section{REFERENCES}

Allemann, F., Wiedmann, J. and Grün, W., 1975. The Berriasian of Caravaca (Prov. of Murcia) in the subbetic zone of Spain and its importance for defining this stage and the Jurassic-Cretaceous boundary: Mémoires Bureau Recherches Geol. Minieres, v. 86, p. 14-22.

Barnard, T. and Hay, W.W., 1974. On Jurassic coccoliths: a tentative zonation of the Jurassic of Southern England and North France: Eclog. Geol. Helv., v. 67, p. 563-585. 
Berger, W.H. and Roth, P.H., 1975. Oceanic micropaleontology: progress and prospect: Rev. Geophys. Space Phys., v. 13, p. 651-635.

Black, M., 1971. Coccoliths of the Speeton Clay and Sutterby Marl: Yorkshire Geol. Soc. Proc., v. 38, p. 381-424.

1972. British Lower Cretaceous Coccoliths. 1. Gault Clay. Part 1: Palaentol. Soc. Mono., p. 1-48.

Brönnimann, P., 1955. Microfossils incertae sedis from the Upper Jurassic and Lower Cretaceous of Cuba: Micropaleontology, v. 1, p. 28-51.

Bukry, D., 1969. Upper Cretaceous coccoliths from Texas and Europe: University of Kansas Paleontol. Contrib., Article 51 (Protista 2), p. 1-79.

Bukry, D., 1972. Coccolith Stratigraphy Leg 11 Deep Sea Drilling Project. In Hollister, C.D., Ewing, J.I., et al., Initial Reports of the Deep Sea Drilling Project, Volume 11: Washington (U.S. Government Printing Office), p. 475-482.

Bukry, D. and Bramlette, M.N., 1969. Coccolith age determinations Leg 1, Deep Sea Drilling Project. In Ewing, M. et al., Initial Reports of the Deep Sea Drilling Project, Volume 1: Washington (U.S. Government Printing Office), p. 369-387.

Cooper, W.W. and Shaffer, B.L., 1976. Nannofossil biostratigraphy of the Bossier Shale and the JurassicCretaceous Boundary: Gulf Coast Assoc. Geol. Sco. Trans., v. 26 , p. $178-184$.

Deflandre, G., 1939. Les stéphanolithes, représents d'un type nouveau de coccolithes du Jurassique supérieur: C.R. Acad. Sci., v. 208, p. 1331-1334.

Deflandre, G. and Fert, C., 1954. Observations sur les coccolithophoridés actuels et fossiles en microscopie ordinaire et électronique: Annales de Paléontologie, v. 40, p. 115-176.

Grün, W. and Allemann, F., 1975. The Lower Cretaceous of Caravaca (Spain) Berriasian calcareous nannoplankton of the Miravetes Section (Subbetic Zone, Prov. of Murcia): Eclog. Geol. Helv., v. 68, p. 147-211.

Grün, W., Kittler, G., Lauer, G., Papp, A., Schnabel, W., and Corna, O., 1972. Studien in der Unterkreide des Wienerwalds: Jahrb. Geol. B.-A., v. 115, p. 103-186.

Habib, D., 1972. Dinoflagellate stratigraphy Leg 11, Deep Sea Drilling Project. In Hollister, C.D., Ewing, J.I., et al., Initial Reports of the Deep Sea Drilling Project, Volume 11: Washington (U.S. Government Printing Office), p. 367381.

Lehmann, R., 1972. Microfossils in thin sections from the Mesozoic deposits of Leg 11, Deep Sea Drilling Project: In Hollister, C.D., Ewing, J.I., et al., Initial Reports of the Deep Sea Drilling Project, Volume 11: Washington (U.S. Government Printing Office), p. 659-663

Lezaud, L., 1967. Nannofossiles calcaires du Jurassique superieur de la Baie de Seine: Soc. Geol. Normandie Bull., v. 57, p. $15-20$.

Manivit, H., 1966. Sur quelques coccolithes nouveaux du Neocomian: C.R. Soc. Géol. France, v. 7, p. 267-269.

Medd, A.W., 1971. Some Middle and Upper Jurassic Coccolithophoridae from England and France. In Farinacci, A. (Ed.), Second Plankt. Conf. Proc., Rome 1970, v. 2, Rome (Tecnoscienza), p. 821-845.

Noël, D., 1956. Coccolithes des terrains Jurassique de l'Algérie: Publ. Serv. Carte Géol. Algérie, n. ser., v. 8, p. $303-345$.

1958. Etude de coccolithes du Jurassique et du Cretacé inférieur: Publ. Serv. Carte Géol. Algérie, n. ser., v. 20 , p. $155-196$

1965a. Sur les coccolithes du Jurassique européen et d'Afrique du Nord. Essai de classification des coccolithes fossiles: Centre National de la Recherche Scientific Paris, p. 1-212.

1965b. Note préliminaire sur des coccolithes jurassiques. Cahiers de Micropaleontologie, sér. 1, 1: Arch. orig. Centre Documentation-Centre National de la Recherche Scientifique, v. 408, p. 1-12.

1972 (1973). Nannofossiles calcaires de sédiments jurassiques finement laminés: Muséum National d'Histoire Naturelle Bull., ser. 3, v. 75, Sciences de la Terre 14, p. 95-156.

Proto Decima, F., 1974. Leg 27 calcareous nannoplankton. In Robinson, P.T., Bolli, H.M., et al., Initial Reports of the Deep Sea Drilling Project, Volume 27: Washington (U.S. Government Printing Office), p. 589-622.

Renz, O., 1972. Aptychi (Ammonoidea) from the Upper Jurassic and Lower Cretaceous of the western North Atlantic (Site 105, Leg 11, DSDP). In Hollister, C.D., Ewing, J.I., et al., Initial Reports of the Deep Sea Drilling Project, Volume 11: Washington (U.S. Government Printing Office), p. 607-620.

Rood, A.P. and Barnard, T., 1972. On Jurassic coccoliths: Stephanolithion, Diadozygus and related genera: Eclog. Geol. Helv., v. 65, p. 327-342.

Rood, A.P., Hay, W.W., and Barnard, T., 1971. Electron microscope of Oxford Clay coccoliths: Eclog. Geol. Helv., v. 64 , p. $245-272$.

Stradner, H., 1963. New contributions to Mesozoic stratigraphy by means of nannofossils: Sixth World Petrol. Congr. Proc., Frankfurt am Main, Section 1, paper 4, p. 167-183.

Stradner, H., Adamiker, D., and Maresch, O., 1968. Electron microscope studies on Albian calcareous nannoplankton from the Delft 2 and Leidschendam 1 Deepwells, Holland: Verhandelingen der Koninklijke Nederlandse Akademie van Wetenschappen, aft. Natuurkunde, Eerste Reeks, v. 24, p. 1-107.

Thierstein, H.R., 1971. Tentative Lower Cretaceous calcareous nannoplankton zonation: Eclog. Geol. Helv., v. 64 , p. $459-488$.

, 1973. Lower Cretaceous calcareous nannoplankton biostratigraphy: Abhandl. Geol. Bundesanstalt, v. 29 , p. $1-52$.

1975. Calcareous nannoplankton biostratigraphy at the Jurassic-Cretaceous boundary: Memoires Bureau Recherches Géol. Minieres, v. 86, p. 84-94.

, 1976. Mesozoic calcareous nannoplankton biostratigraphy of marine sediments. Marine Micropaleontol., v. 1, p. 325-362.

Trejo, M., 1960. La Familia Nannoconidae y su alcance estratigrafice en America: Bol. Asoc. Mexicana de Geologos Petroleo, v. 12, p. 259-314.

1969. Conusphaera mexicana, un nuevo cocolitoforido del Jurasico superior de Mexico: Rev. Inst. Mexicano del Petroleo, v. 1, p. 5-15.

1975. Los Tintinidos mesozoicos de Mexico: Memoires Bureau Recherches Géol. Minieres, v. 86, p. 95104.

van Hinte, J.E., 1976. A Jurassic time scale: Am. Assoc. Petrol. Geol. Bull., v. 60, p. 489-497.

Wilcoxon, J.A., 1972a. Upper Jurassic-Lower Cretaceous calcareous nannoplankton from the western North Atlantic Basin. In Hollister, C. D., Ewing, J.I., et al., Initial Reports of the Deep Sea Drilling Project, Volume 11: Washington (U.S. Government Printing Office), p. 427458 .

1972b. Calcareous nannoplankton ranges, Deep Sea Drilling Project: Ibid., p. 459-473. 
Wise, S.W. and Wind, F.H., 1977. Mesozoic and Cenozoic calcareous nannofossils recovered by DSDP Leg 36 drilling on the Falkland Plateau, Atlantic sector of the Southern Ocean. In Barker, P.F., Dalziel, I.W.D., et al., Initial Reports of the Deep Sea Drilling Project, Volume 36: Washington (U.S. Government Printing Office), p. 269. 492.
Worsley, T.R., 1971. Calcareous nannofossil zonation of Upper Jurassic and Lower Cretaceous sediments from the western Atlantic. In Farinacci, A. (Ed.), Second Plankt. Conf. Proc., Rome, 1970, v. 2: Rome (Tecnoscienza), p. $1301-1321$. 


\section{PLATE 1}

Upper Jurassic Nannofossils From Hole 391C

Figures 1-4 Stephanolithion bigoti Deflandre.

1, 2. Phase-contrast, crossed-polarized light; $4000 \times$. Sample 391C-52, CC.

3, 4. Phase-contrast, crossed-polarized light; $4000 \times$. Sample $391 \mathrm{C}-51-2,116 \mathrm{~cm}$.

Figure 5 Hexapodorhabdus cuvillieri Noël; phase-contrast; $4000 \times$. Sample $391 \mathrm{C}-50-1,61 \mathrm{~cm}$.

Figures 6,7 Cruciellipsis cuvillieri (Manivit); phase-contrast, crossed-polarized light; $4000 \times$. Sample 391C-47-1, $79 \mathrm{~cm}$.

Figures 8,9 Cretarhabdus quadratus (Black), Wind, n. comb.; phase-contrast, crossed-polarized light, 4000×; Sample 391C-51-2, $116 \mathrm{~cm}$.

Figure 10 Nannoconus sp. aff. $N$. dolomiticus crossedpolarized light; 4000X; Sample 391C-47-1, $79 \mathrm{~cm}$.

Figures 11, 12 Cretarhabdus conicus Bramlette and Martini; phase-contrast, crossed-polarized light; 4000X; Sample 391C-51-2, $116 \mathrm{~cm}$.

Figure $13 \quad$ Nannoconus bronnimanni Trejo; crossed-polarized light; 4000×; Sample 391C-49-2, $72 \mathrm{~cm}$.

Figures 14, 20 ?Nannoconus sp. aff. $N$. bermudezi Bronnimann; crossed-polarized light; $4000 \times$; Sample 391C-52-4, $48 \mathrm{~cm}$.

Figures 15-17 Nannoconus steinmanni Kamptner.

15. Crossed-polarized light; $4000 \times$; Sample 391C$48-2,129 \mathrm{~cm}$.

16, 17. Phase-contrast, polarized light; 5100X; Sample 391C-49-2, $72 \mathrm{~cm}$.

Figures 18, 19 ?Nannoconus sp.; crossed-polarized light; 4000×; Sample 391C-50-1, $90 \mathrm{~cm}$.

Figure 21 Conusphaera mexicana Trejo and Polycostella beckmannii Thierstein; crossed-polarized light; 4000×; Sample 391C-48-2, $129 \mathrm{~cm}$. Soon after their first appearance in the section, C. mexicana (c) and $P$. beckmanni $(\mathrm{p})$ are the dominant nannoplankton-remains in the sediments.

Note: Phase-contrast micrographs (Figures 1, 5, 6,8 , and 11) are from carbon- and gold-palladium coated slides. Crossed-polarized light micrographs are oriented with the optical axes parallel to the page axes. 
PLATE 1

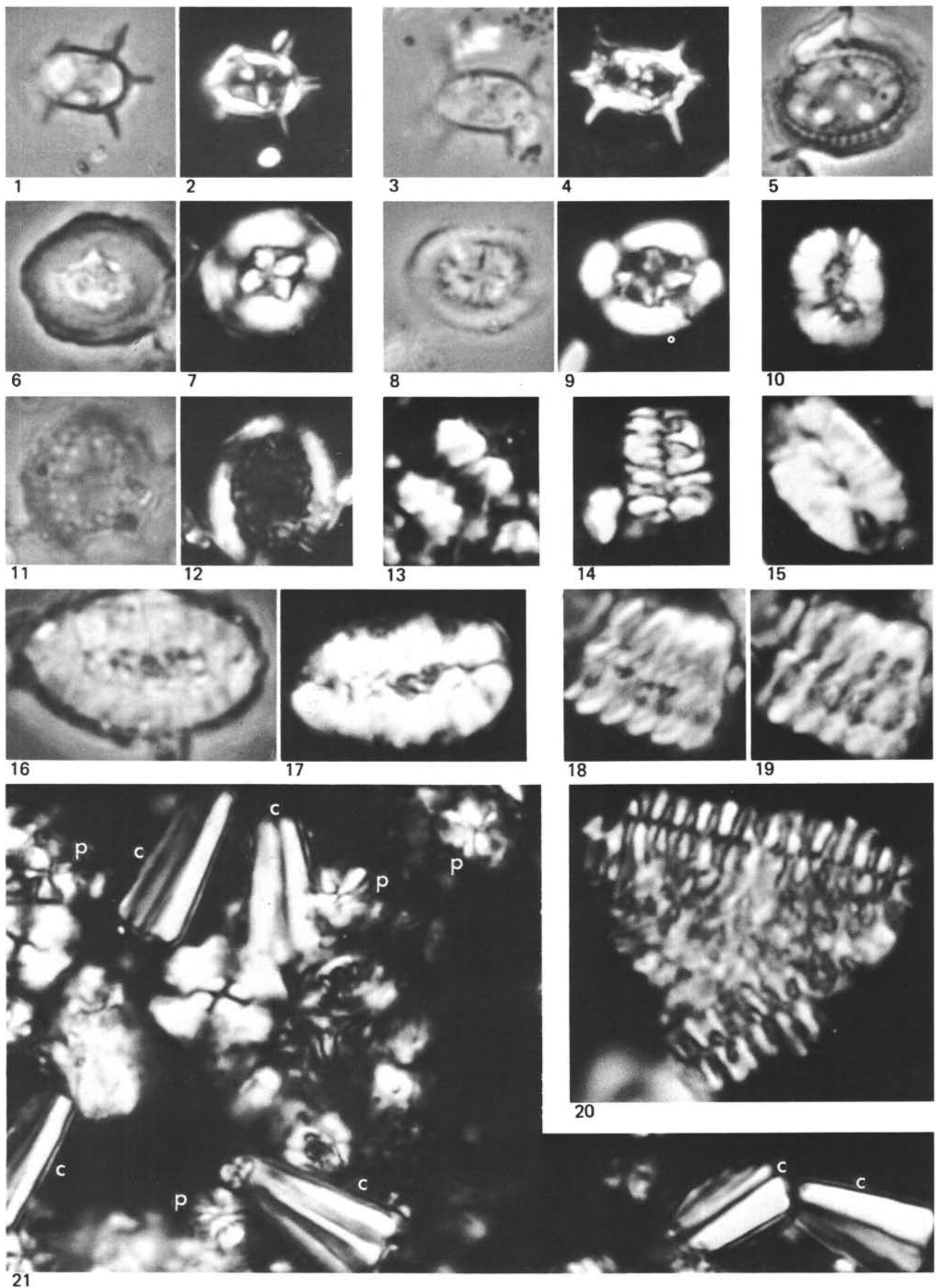

